\title{
CASE COMMENT: HALPERN V. CANADA (A.G.)
}

\author{
JULIE C. LLOYD*
}

\section{INTRODUCTION}

Halpern v. Canada (A.G. $)^{1}$ is another voice in the growing chorus of jurists who have identified the exclusion of same-sex couples from the institution of marriage as a violation of the Canadian Charter of Rights and Freedoms. ${ }^{2}$ Appellate courts in British Columbia ${ }^{3}$ and Quebec ${ }^{4}$ have reached similar conclusions. It appears, however, that the choir might have given its last concert, as Prime Minister Jean Chrétien recently promised to draft a bill creating a definition of marriage that removes the exclusion of same-sex couples. ${ }^{5}$

While the issue of same-sex marriage has generated significant discourse in recent months, it has become less interesting from a jurisprudential perspective. Years ago, Canadian courts arrived at a crossroads in terms of defining the content of equality rights for gay and lesbian litigants. The decision of the Supreme Court of Canada in Egan v. Canada demonstrated a serious division in the equality analysis appropriate to same-sex couples. The question of how these issues would be resolved was the most significant source of nail-biting among gay and lesbian litigants as well as the counsel who represented them. The division was resolved in subsequent decisions, particularly in $M . v . H^{7}$ and, in the end, all sustainable Charterbased objection to same-sex marriage was eventually eliminated, making the decision in Halpern inevitable.

In this comment, I identify some of the obstacles to substantive equality for lesbian and gay litigants, characterize the manner in which those obstacles were resolved, lay out the elements of the Halpern decision, and ultimately argue that those elements had already been firmly established in earlier jurisprudence.

\section{A Review of the Evolution of Judicial REASONING IN THE CONTEXT OF GAY AND LESBIAN EQUALITY CLAIMS}

The judgment in Egan stood at the crossroads of lesbian and gay equality aspirations. In that case, the Supreme Court of Canada considered the constitutionality of excluding samesex couples from a benefit created under the Old Age Security Act. ${ }^{8}$ In a unanimous decision, the Court found that sexual orientation was an analogous ground of discrimination under $s$. 15(1) of the Charter; however, the Court was seriously divided on the implications of that

Barrister and Solicitor, Edmonton, Alberta.

(2003), 225 D.L.R. (4th) 529 [Halpern] (Ont. C.A.).

2 Part 1 of the Constitution Act, 1982 being Schedule B to the Canada Act 1982 (U.K.), 1982, c. 11 [Charter].

EGALE Canada v. Canada (A.G.) (2003), 255 D.L.R. (4th) 472.

Hendricks c. Québec (P.G.) (2003), J.E. 2003-466.

"Ottawa asks top court to set stage for new gay marriage law" Edmonton Journal (7 July 2003) A1.

[1995] 2 S.C.R. 513 [Egan]. See also B. Berg, "Fumbling Towards Equality: Promise and Peril in Egan" (1995) 5 N.J.C.L. 263.

[1999] 2 S.C.R. 3 [M. v. H.].

8 R.S.C. 1986, c. O-9. 
finding. In the end, the majority agreed that the social objectives of the Old Age Security Act did not encompass homosexual relationships, and thus found the exclusion to be consistent with the Charter.

Justice LaForest, representing a minority of four judges, found no violation of s. 15(1). He reasoned that while the exclusion created both distinction and disadvantage, there was no discrimination because same-sex and opposite-sex couples were fundamentally different in form, purpose, and function. In addition, he found that the legislative purpose of the Old Age Security Act was directed exclusively towards heterosexual couples. Justices Cory and Iacobucci, also representing a minority of four, ${ }^{9}$ found a violation of s. 15(1) and found that the discrimination was not demonstrably justified under $\mathrm{s}$. 1 . The majority decision was written by Sopinka J., who held that, while the exclusion violated s. 15(1), it was demonstrably justified pursuant to $\mathrm{s} .1$.

The minority decision of LaForest $\mathrm{J}$. was immediately criticized as a descent into formalism a full six years after the Supreme Court's decision in Andrews v. Law Society of British Columbia ${ }^{10}$ had marked a decisive move away from formalism, towards an effectsbased analysis of s. 15 claims under the Charter. ${ }^{11}$ For lesbian and gay litigants and their counsel, however, there were a number of troubling and familiar elements to the analysis employed by the LaForest J. minority - elements that would seriously curtail their chances of securing substantive equality before the courts.

\section{A. The Scope of the Protections Included in "Sexual Orientation" - Does the Ground Extend to SAME-SEX Couples?}

After agreeing that sexual orientation was an analogous ground of discrimination under s. 15(1), LaForest J. went on to conclude that the exclusion of same-sex couples from the Old Age Security Act did not violate the Charter. Indeed, his minority reasons found that the exclusion was not discriminatory even during a s. 15(1) analysis and, accordingly, found that a s. 1 analysis was not engaged. The result in Egan was not uncommon. Other courts and arbitrators had held, similarly, that the inclusion of sexual orientation as a prohibited ground of discrimination could co-exist quite comfortably alongside opposite-sex definitions of the term "spouse" within legislation and collective agreements. ${ }^{12}$

9 For sake of clarity, referred to here as the second constituency (see text accompanying infra notes 32 $34)$.

10 [1989] 1 S.C.R. 143 [Andrews]. For a more substantial analysis of inconsistent approaches to s. 15(1), see M. Moran, "Formal Equality v. Substantive Equality: The Boys vs. the Girls" in $A$ Court Divided: Equality Rights and the Supreme Court of Canada (Toronto: Law Society of Upper Canada, 1995).

"See e.g. the reasons of McLachlin J. in Miron v. Trudel, [1995] 2 S.C.R. 418.

12 See Layland v. Ontario (Minister of Consumer and Commercial Relations (1993), 104 D.L.R. (4th) 214 (Ont. Div. Ct.), an application of s. 15(1) to the issue of same-sex marriage wherein it was found that the exclusion of same-sex couples did not violate s. 15(1). See also Vogel v. Manitoba (1992), 90 D.L.R. (4th) 84 (Man. Q.B.), a case concerning same-sex couples and employment benefits where, at 101 , the Court found that "[t]he sexual orientation of the complainants is a matter of their individual preference or lifestyle" and further, that same-sex couples therefore are not entitled to the same employment benefits as are opposite-sex couples. See generally Re Treasury Board (Indian and Northern Affairs) v. Watson (1990), 11 L.A.C. (4th) 129; Re Carlton University and C.U.P.E., Local 2424 (1988), 35 L.A.C. (3d) 96. 
These results were particularly troubling to gay and lesbian litigants because sexual orientation is relational in nature. That is, one is identified as gay or lesbian because of the manner in which one forms intimate relationships. Should any prohibition against discrimination on the basis of sexual orientation not extend to same-sex relationships, any bid for substantive equality would be reduced to a vain hope.

\section{EGAN V. CANADA - THE CONFLICT}

Justice LaForest's analysis in Egan suggested that sexual orientation, as a prohibited ground of discrimination, might protect individual gay and lesbian litigants, but it would not protect same-sex couples. For him, same-sex couples do not suffer discrimination when excluded from statutory instruments that include heterosexual couples. Instead, same-sex relationships are merely included in references to other non-spousal relationships. ${ }^{13}$

Justice Cory, writing for the other minority of four, took a different approach. $\mathrm{He}$ recognized that sexual orientation, a prohibited ground of discrimination under the Charter, must be extended to include same-sex relationships: "Sexual orientation is more than a status that an individual possesses. It is something demonstrated in an individual's conduct by the choice of a partner.... It follows that a lawful relationship which flows from sexual orientation should also be protected." ${ }^{14} \mathrm{He}$ concluded that "[t]he sexual orientation of the individual members cannot be divorced from the homosexual couple. To find otherwise would be as wrong as saying that being pregnant had nothing to do with being female."15 After embracing the relational quality of this prohibited ground of discrimination by linking it directly to a couple rather than a singular identity, Cory J. concluded that the exclusion of same-sex couples from access to benefits is discriminatory.

\section{M. V. H. - THE RESOLUTION}

$M$. v. $H$. was a challenge to the exclusion of same-sex couples from the spousal support provisions in the Family Law Act ${ }^{16}$ of Ontario. Justice Cory, writing for the majority on the s. 15(1) and s. 1 analyses, did not expressly return to the fundamental question of whether "sexual orientation" as a prohibited ground of discrimination extends to same-sex couples. However, precisely this type of exclusion was found to have violated the equality provisions of the Charter. In the end, the Charter was found to apply not only to individual gays and lesbians, but to their relationships as well. ${ }^{17}$

\section{B. ARE THERE Legally ReleVANT DifferenCES BetWeEN SAME- AND OPPOSITE-SEX COUPLES?}

Another historical obstacle to the substantive equality claims of gay and lesbian litigants was the view that same-sex relationships and opposite-sex relationships are fundamentally different in form, function, and purpose from heterosexual relationships. As long as same-sex

13. Such as siblings who live together (Egan, supra note 6 at para. 24).

Ibid. at para. 175.

Ibid. at para. 168.

16 R.S.O. 1990, c. F-3, s. 29.

17 M. v. H., supra note 7. 
relationships were seen as dissimilar in this manner, however, the chances of achieving substantive equality remained slim.

\section{CANADA (A.G.) v. MOSSOP - THE CONFLICT}

Pre-dating Egan, the first serious judicial engagement with the issue of dissimilarity is found in the 1993 decision of Canada (A.G.) v. Mossop. ${ }^{18}$ In Mossop, the Supreme Court of Canada considered whether "family status," a prohibited ground of discrimination under the Canada Human Rights Act, ${ }^{19}$ could be relied upon to challenge the exclusion of same-sex couples from a bereavement leave benefit. At that time, sexual orientation was not an enumerated ground under the Human Rights Act.

Justice Lamer, writing for a majority of four, found that the ground of "family status" could not be applied to same-sex couples. The discrimination suffered by Mr. Mossop, he reasoned, arose from his sexual orientation rather than from his family status. Justice LaForest, writing a concurring judgment, expanded on the definition of family status and found that "the dominant conception of family is the traditional family." ${ }^{20}$ Unfortunately, same-sex couples were not included in this dominant view and thus did not fall within the traditional definition of "family."

Justice L'Heureux-Dubé wrote a dissenting decision in which McLachlin and Cory JJ. concurred. In this decision, L'Heureux-Dubé J. none-too-gently accused her colleagues of labouring under the burden of "unexamined consensus" 21 in their determination that same-sex couples were excluded from the concept of "family." She insisted that a functional view of family structures could lead only to an appreciation that family forms vary widely and that '[t]he traditional conception of family is not the only conception." ${ }^{22}$ She concluded her analysis by suggesting that, "it is not anti-family to support protection for non-traditional families. The traditional family is not the only family form and non-traditional family forms may equally advance true family values." ${ }^{\prime 23}$ In subsequent decisions, other justices accepted L'Heureux-Dubé J.'s challenge.

\section{EGAN V. CANADA - THE CONFLICT CONTINUES}

In Egan, LaForest J. took the view that heterosexual couples and homosexual couples were fundamentally dissimilar in form and function. He found the difference to be "firmly anchored" in the "biological and social realit(y) that heterosexual couples have the unique ability to procreate, that most children are the product of these relationships, and that they are generally cared for and nurtured by those who live in that relationship."24 
A position contrary to this was first articulated by Cory J. in Egan and then later in $M . v$. $H$. Justice Cory observed that counsel for Mr. Egan and his partner had invested considerable effort in portraying their relationship as loving, longstanding, ideal, and similar in form to a heterosexual relationship. He directed that

It is not necessary that the evidence demonstrate that a homosexual relationship bears all the features of an ideal heterosexual relationship, for the relationships of many heterosexual couples is far from ideal. The relationships between heterosexual couples must vary infinitely as do the personalities of the individuals involved. $^{25}$

In the end, to qualify for Charter protection, it was not even necessary for same-sex couples to show that their relationships mirrored some idealized conception of heterosexual relationships. The question of whether excluding same-sex couples violated s. 15(1) would not be decided on the basis of whether or not these two types of conjugal relationships were identical in form, function, and purpose.

\section{M. V. H. - THE RESOLUTION}

In $M . v . H$. Cory J. took matters one step further by creating a factual equation between same-sex and opposite-sex couples for the purposes of Charter analysis. "Certainly," he found, "same-sex couples will often form long, lasting, loving and intimate relationships." 26 Further, he found that same-sex couples, like opposite-sex couples, can and do share the "generally accepted characteristics of a conjugal relationship." 27 Justice Cory also noted that same-sex couples have children and live in interdependent relationships.

Gay and lesbian relationships have now been given a proper place within the framework of family relationships. This critical development makes clear that any legislation that treats same-sex and opposite-sex relationships differently is unlikely to meet the s. 15(1) requirements of the Charter. Indeed, in $M . v$. $H$., Iacobucci J. expressly invited the legislature of Ontario to review all statutory instruments that excluded same-sex couples. ${ }^{28}$

\section{The Definition of Legislative Purpose}

Another question of fundamental importance to gay and lesbian litigants pertained to how the purpose of legislation that included opposite-sex couples but excluded same-sex couples was to be defined. Would an "unexamined consensus" of family in and of itself be sufficient to form the basis for defining a legislative purpose consistent with the goals of gay and lesbian litigants? This argument was critical: were heterosexuality found to inform or define the purpose of exclusive legislation, substantive equality for same-sex relationships would remain an impossible goal.

25 Ibid. at para. 169. For additional discussion, see Janet E. Halley, "Sexual Orientation and the Politics of Biology: A Critiqué of the Argument Form Immutability" (1994) 46 Stan. L. Rev. 503 at 516-17: "an essentialist view of homosexual orientation claims it is a deep-rooted, fixed and intrinsic feature of individuals... The constructivist view of homosexual orientation claims that it is a contingent socially malleable trait that arises in a person as she manages her world, its meaning, and her desires."

28 Ibid. at para. 147. 


\section{EGAN V. CANADA - THE CONFLICT}

In Egan, LaForest J. found that the legislative purpose of the Old Age Security Act ${ }^{29}$ included heterosexuality as a critical defining aspect. He drew considerable response from critics who challenged the legislative purpose as located within his s. 15(1) analysis, rather than his $\mathrm{s.} 1$ analysis. ${ }^{30}$ Regardless of its location, that analysis had significant implications for the substantive equality claims of same-sex couples.

Justice LaForest found the legislative purpose of the Old Age Security Act to be "firmly anchored in the biological and social realities that heterosexual couples have the unique ability to procreate, that most children are the product of these relationships, and that they are generally cared for and nurtured by those who live in that relationship." ${ }^{31} \mathrm{He}$ concluded his analysis with little examination of the internal workings of the legislation itself or the reality of the heterosexual family. In particular, La Forest J. was unswayed by the reality that childless heterosexual couples qualify for a benefit (and presumably equally unswayed by the reality that some same-sex couples have children, but are denied that benefit): "I am not troubled by the fact that not all these heterosexual couples in fact have children. It is the social unit that uniquely has the capacity to procreate."132

Justice Iacobucci, writing the s. 1 portion of the second constituency in Egan, argued that legislative purpose must be defined in a manner that is supported both by evidence and by the legislation itself. ${ }^{33}$ Employing a more rigorous analysis, Iacobucci J. rejected the various legislative objectives proposed by the Crown. First, as both men and women could apply for a benefit under the $A c t$, the legislative objective could not be that of protecting women and redressing the feminization of poverty arising from child care roles. Second, it could not be that of encouraging and supporting the procreation of children and redressing the consequences of that role. Simply put, there was no acceptable rationale for the exclusive benefit to child-bearing couples.

\section{M. V. H. - THE RESOLUTION}

In $M . v . H$., the majority preferred the analysis of Iacobucci J. over that of LaForest J. in Egan. The majority in $M . v$. H. dismissed the notion that the legislative purpose of the $A c t$ in question was related to heterosexuality, procreation, or to redressing the consequences of childcare. These propositions were belied by the reality that both men and women, and not just primary caregivers, could apply for support and, further, by the fact that childlessness did not serve as a bar to a support application. As a result, the legislative purpose of spousal support provisions was held to be the redress of economic hardships that arise when intimate relationships break down, regardless of sexual orientation. Legislative purpose, therefore, was not automatically defined by presumed "biological and social realities" of heterosexuality. ${ }^{34}$

29) Supra note 8.

30) See Miron v. Trudel, supra note 10 at para. 135, McLachlin J.

Egan, supra note 6 at para. 21.

Ibid. at para. 25.

See ibid. at paras. $132-231$

M. v. H., supra note 7. 


\section{CONSEQUENCES OF EXCLUSION}

Another issue of importance to lesbian and gay equality litigants was the question of how courts would view the effects of excluding same-sex relationships. In particular, would the courts be sensitive to the societal or symbolic effects of such an exclusion?

\section{EGAN V. CANADA-THE CONFLICT}

Justice LaForest's decision in Egan rendered irrelevant any consideration of whether the exclusion of same-sex couples from the legislation in question creates either practical or symbolic harm to gays and lesbians. Simply put, he found that the exclusion of same-sex couples was relevant to the purpose of the legislation: that is, the protection of heterosexual relationships. Given that the distinction was found to be relevant with a compatible legislative objective, the s. 15(1) analysis proceeded no further. Justice LaForest's decision implied that the exclusion of same-sex couples created no harm. Rather, it was assumed that such exclusion benignly grouped same-sex couples together with other non-spousal relationships for the purposes of the legislation at hand.

The second constituency in Egan took a different view, and traced the roots of prejudice to a denial of the benefit at issue. Importantly, however, the practical consequences extending from that denial were considered to be only one of the potential sources of discrimination. Equally important was an appreciation of the symbolic consequences of exclusion. As the Court noted, "[t]he law confers a significant benefit by providing state recognition of the legitimacy of a particular status. The denial of the recognition may have a serious detrimental effect upon the sense of self-worth and dignity of members of a group because it stigmatizes them even though no economic loss is occasioned." 35 As a result, the Court moved beyond the merely functional analysis and examined in detail the less direct adverse effects of the exclusion.

\section{M. V. H. - THE RESOLUTION}

In $M . v . H$. , Cory J. identified the importance of the symbolic elements in the exclusion of same-sex couples:

The societal significance of the benefit conferred by the statute cannot be overemphasized. The exclusion of same-sex partners from the benefits of s. 29 of the FLA promotes the view that M., and individuals in samesex relationships generally, are less worthy of recognition and protection. It implies that they are judged to be incapable of forming intimate relationships of economic interdependence as compared to opposite-sex couples, without regard to their actual circumstances. ${ }^{36}$

The Supreme Court of Canada has been quite clear that the societal or symbolic consequences of exclusion constitute a harm that the Charter is designed to protect. This articulation has important implications for the substantive equality claims of lesbian and gay litigants, including a challenge to heterosexual marriage. For even if equal treatment of same- 
sex and opposite-sex couples might be achieved through a partnership registry or other such methods, denying a right to marry will unavoidably attract the application of a societal or symbolic harm analysis.

\title{
E. JUSTIFICATION VERSUS EXPLANATION — The Weight of A Pedigree of Exclusion
}

Another issue of some significance to the outcome of substantive equality claims by gays and lesbians was that their exclusion has been pervasive and long-standing. If pedigree and the pervasiveness of exclusion were considered relevant justification for its occurrence, substantive equality would be difficult to justify.

\section{EGAN V. CANADA - THE CONFLICT}

Justice LaForest took comfort in the widespread and long-standing history of exclusion faced by same-sex couples in Canada. ${ }^{37} \mathrm{~A}$ different view was enunciated by Cory J. in Egan:

The fact that, in the past, the term "spouse" had only a heterosexual connotation must not serve to prevent an inquiry into whether the statutory definition limiting "spouse" only to heterosexual couples violates s. 15(1) of the Charter. This principle was emphasized in Turpin where at p. 1328 Wilson J. wrote:

\begin{abstract}
The argument that s. 15 is not violated because departures from its principles have been widely condoned in the past and that the consequences of finding a violation would be novel and disturbing is not, in my respectful view, an acceptable approach to the interpretation of Charter provisions. ${ }^{38}$
\end{abstract}

The Court therefore found that one cannot rely upon the historical exclusion of gays and lesbians to rationalize or condone ongoing discrimination against them.

\section{M. V. H. - THE RESOLUTION}

In M. v. H., the exclusion of same-sex couples from Ontario's Family Law $A c t^{39}$ was found to violate the Charter, even though the exclusion of same-sex couples was a familiar incident of the legislation in that province. In his discussion of remedy, Iacobucci J. observed that the Court's finding that s. 29 of the Family Law Act was unconstitutional meant that it "may well offset numerous other statutes that rely on a similar (heterosexual) definition of the word 'spouse." "40 Indeed, the Province of Ontario amended 67 statutes in response to the ruling in M. v. $H{ }^{41}$ As such, the pervasiveness and historical pedigree of exclusion was not considered relevant to Charter analysis.

Ibid. at paras. 19-22; 28-31.

Ib Ibid. at para. 166.

"') Supra note 18.

"1) Egan, supra note 6.

${ } 1$ Amendments Because of the Supreme Court of Canada's Decision in M. v. H. Act, S.O. 1990, c-6. 


\section{F. THE NATURE OF MARRIAGE}

The Supreme Court of Canada has recently discussed the nature of marriage and the nature of the right to enter into the institution. Justice Bastarache, writing for the majority in Nova Scotia (A.G.) v. Walsh, identified choice in respect to marriage as a Charter value: "One of those essential [Charter] values is liberty, basically defined as the absence of coercion and the ability to make fundamental choices with regard to one's life. Limitations imposed by this Court that serve to restrict this freedom of choice among persons in conjugal relationships would be contrary to our notions of liberty." ${ }^{42}$ In light of this decision, it will now be difficult to argue that depriving a couple of the right to marry is a trivial or unimportant matter.

\section{G. CONClusion}

At the conclusion of the journey from Egan to $M . v$. H., we know that s. 15(1) applies to same-sex relationships and that same-sex relationships are not different in any relevant way from opposite-sex relationships. In addition, we know that legislative purpose would not be defined from an "unexamined consensus" of heterosexuality and, further, that both practical and symbolic prejudice to gays and lesbians are matters of Charter concern. Moreover, we know that although a pedigree of exclusion might explain discrimination, it will not serve as its justification. Finally, we know that marriage is an institution fundamental to Canadian society and that the freedom to choose one's conjugal partner is a critical incident of citizenship in Canada.

What is left, one wonders, to sustain marriage as a heterosexual institution? Once the Charter demands full substantive equality for same-sex couples, to insist that marriage alone be preserved for heterosexuals seems a position difficult to sustain - even a little churlish.

\section{HALPERN V. CANADA (A.G.)}

In Halpern, the Ontario Court of Appeal unanimously upheld the s. 15(1) and s. 1 conclusions of the Ontario Divisional Court. The Court of Appeal varied only the remedy selected. The Charter analysis employed by the Court was short and to the point. As a result, the Crown's arguments were dispensed with quickly and emphatically.

\section{A. SECTION 15(1) OF THE CHARTER}

Given the robust quality of s. 15(1) jurisprudence that is now applied to same-sex relationships, it is not surprising that the Crown's primary argument in Halpern was one inviting the Court to avoid the application of s. 15(1) altogether. It is also not surprising, then, that the Crown's invitation was declined.

The Crown argued that no distinction is drawn between same-sex and opposite-sex couples. Instead, the exclusion of same-sex couples from marriage arises from the very definition of marriage as an exclusively heterosexual notion. The Crown's argument, therefore, was that no distinction arises from the reality of this definition. 
The Court of Appeal began by rejecting this invitation to revisit the road of formalism, correctly identifying the "just is" argument as circular:

an argument that marriage is heterosexual because it 'just is' amounts to circular reasoning. It sidesteps the entire s. 15(1) analysis. It is the opposite-sex component of marriage that is under scrutiny. The proper approach is to examine the impact of the opposite-sex requirement on same-sex couples to determine whether defining marriage as an opposite-sex institution is discriminatory. ${ }^{43}$

Further, recognizing that the distinction might arise from the definition of marriage does not change the fact that a distinction is made. As the Court stated, "[i]f marriage were defined as 'a union between one man and one woman of the Protestant faith,' surely the definition would be drawing a formal distinction between Protestants and all other persons." ${ }^{\text {44 }}$ Applying Eldridge v. British Columbia (A.G.), ${ }^{45}$ the Court observed that Canada has chosen to give legal recognition to marriage and has built a myriad of rights and obligations around the institution of marriage. As a result, the Court concluded that once the state elects to provide a benefit, it is obliged to do so in a non-discriminatory manner.

The Court also declined to attach Charter consequence to the reality that the exclusion of same-sex couples from marriage has been long-standing. Indeed, they found "that marriage is heterosexual because it always has been heterosexual is merely an explanation for the opposite-sex requirement of marriage; it is not an objective that is capable of justifying the infringement of a Charter guarantee." ${ }^{46}$

Similar to LaForest's discussion in Egan, the Crown's argument relied upon a conceptualization of same-sex and opposite-sex couples as fundamentally different in form, purpose, and function. Therefore, the Crown's argument rested on the premise that marriage, as a heterosexual institution, corresponds to the capacities, needs, and circumstances of exclusively opposite-sex couples. The institution of marriage thus facilitates, shelters, and nurtures the unique union of a man and a woman who alone have the possibility to bear children and shelter them appropriately. ${ }^{47}$

The Court rejected this argument quickly, citing $M . v . H$. as authority:

While it is true that, due to biological realities, only opposite-sex couples can 'naturally' procreate, same-sex couples can choose to have children by other means, such as adoption, surrogacy and donor insemination. An increasing percentage of children are being conceived and raised by same-sex couples. ${ }^{48}$

Importantly, no one, including the AGC, is suggesting that procreation and childrearing are the only purposes of marriage, or the only reason why couples choose to marry. Intimacy, companionship, societal recognition, economic

48 Ibid. at para. 93. 
benefits, the blending of two families, to name a few, are other reasons that couples chose to marry. As recognized in M. v. H., same-sex couples are capable of forming "long lasting, loving and intimate relationships. ${ }^{49}$

The Court refused to retreat to the formulation articulated in Egan. Instead, the Col' $i t$ found that same-sex and opposite-sex couples are not different in any relevant way. The Court similarly rejected the Crown's argument that discrimination is negated by the existence of the Modernization of Benefits and Obligations Act,${ }^{50}$ by which Parliament amended 68 federal statutes and entitled same-sex couples to the same benefits and obligations as are available to opposite-sex couples.

Instead, the Court found significant practical differences. First, under the Benefits and Obligations Act, rights do not attach until a couple have been living together for the requisite period. Second, not all benefits and obligations have been extended to common law couples and, therefore, to same-sex couples. In Walsh ${ }^{51}$ for example, the exclusion of common law couples from matrimonial property legislation was upheld. The Court also noted the symbolic implications of such exclusion:

In this case, same-sex couples are excluded from a fundamental societal institution - marriage. The societal significance of marriage, and the corresponding benefits that are available only to married persons, cannot be overlooked.... Exclusion perpetuates the view that same-sex relationships are less worthy of recognition than opposite-sex relationships. In doing so, it offends the dignity of persons in same-sex relationships. ${ }^{52}$

The exclusion in Halpern was thus found to violate s. 15(1) of the Charter, at which point the Court considered whether the violation was demonstrably justified under s. 1.

\section{B. SECTION 1}

As heterosexuality itself does not provide a valid legislative purpose, the Crown had a difficult time meeting the requirements of the $s .1$ test set out in $R$. v. Oakes. ${ }^{53}$ In dealing with the question of whether a pressing and substantial purpose has been made out, the Court in Halpern identified the appropriate question as follows:

No one is disputing that marriage is a fundamental societal institution. Similarly, it is accepted that, with limited exceptions, marriage has been understood to be a monogamous opposite-sex union. What needs to be determined, however, is whether there is a valid objective to maintaining marriage as an exclusively heterosexual institution. ${ }^{54}$

The purposes of marriage advanced by the Crown included: (I) uniting the opposite sexes; (ii) encouraging the birth and raising of children of the marriage; and (iii) companionship. ${ }^{55}$ The first proffered purpose, uniting the opposite sexes, was quickly deemed to have no 
pressing and substantial objective, but rather, one that was itself discriminatory. Referring to R. v. Big M Drug Mart, ${ }^{56}$ the Court found that "a purpose that demeans the dignity of same-sex couples is contrary to the values of a free and democratic society and cannot be considered to be pressing and substantial. A law cannot be justified on the very basis upon which it is being attacked." 57

The second proffered purpose, procreation, was also rejected. While encouraging procreation as a laudable goal, the Court held that such is not the legislative purpose of marriage. Procreation has never been a prerequisite thereof. Further, procreation is not a pressing and substantial reason to preserve marriage as an exclusively heterosexual union. Indeed, as the Court indicated, "[h]eterosexual married couples will not stop having or raising children because same-sex couples are permitted to marry. Moreover, an increasing percentage of children are being born to and raised by same-sex couples." ${ }^{\circ 8} \mathrm{~A}$ law that therefore protects "natural" procreation simply "ignores the fact that same-sex couples are capable of having children" 59 by other means, such as adoption, surrogacy, and donor insemination.

The final purpose proffered by the Crown was that of encouraging companionship. The Court found that while companionship is an important part of marriage, encouraging it exclusively between opposite-sex partners could not be a pressing and substantial objective pursuant to s. 1 of the Charter. The exclusion again perpetuated a view that was itself discriminatory. ${ }^{60}$

Having found no pressing and substantial objective for the preservation of marriage as an exclusively heterosexual institution, the Court was not required to proceed further with the s. 1 analysis. The Court did observe, however, that it could find no rational connection between the exclusion of same-sex couples and any of the purposes proffered by the Crown. Indeed, the exclusion maximally, rather than minimally, impaired the equality rights of samesex couples. In the end, the Crown was utterly unable to justify the preservation of heterosexual marriage under the Charter.

\section{REMEDY}

Perhaps the only element of surprise in the Court's decision came with the remedy it selected. Surprise arose not because the Court had extended the jurisprudence relevant to Charter remedy, but rather, because the Court returned to the principles enunciated in Schacter v. Canada, ${ }^{61}$ the leading Canadian case on Charter remedies.

The Court declared the common law definition of marriage to be invalid and reformulated the definition to include same-sex couples. They also declared that the relief ordered would have immediate application, preferring not to suspend the remedy to provide Parliament with

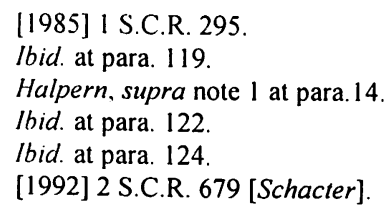


an opportunity to re-fashion the definition of marriage in the interim. Delayed declarations of constitutional invalidity have been a fairly common remedial tool employed by the courts, particularly in the context of legislation impacting interpersonal relationships. ${ }^{62}$ Charter claimants and those they represent are often therefore made to bear the burden of their success during periods of suspended remedies and thus abide by laws that have been found to impair their dignity.

In the context of legislation dealing with relationships, courts in Canada have often ignored the direction in Schachter. ${ }^{63}$ Justice Lamer noted that "[a] delayed declaration allows a state of affairs which has been found to violate standards embodied in the Charter to persist for a time despite the violation." circumstances, such as where striking down the law poses a potential danger to the public or threatens the rule of law. ${ }^{65}$ The exclusion of same-sex couples from the institution of marriage was found by the Court to be a clear and simple matter of equality. As there was no evidence of harm to the public or threat to the rule of law, there was therefore no reason to employ a delay or to insist that same-sex couples continue to abide by a wrongful law.

\section{Conclusion}

In the end, the decision in Halpern and Parliament's subsequent initiative to remove the historic common law exclusion of same-sex couples from marriage came as no surprise. One by one, the questions relevant to a consideration of the constitutionality of same-sex marriage had been posed and emphatically answered in earlier jurisprudence, making the Halpern judgment itself a foregone conclusion.

(2. See M. v. H., supra note 7; Taylor v. Rossu (1998), 161 D.L.R. (4th) 266 (Alta. C.A.); Estate of Sand, [2001] 10 W.W.R. 188 (Alta. Surr. Ct.).

Supra note 61.

(it Ibid. at para. 81 .

is Ibid. at paras. 78-83. 